\title{
DCTPP1 attenuates the sensitivity of human gastric cancer cells to 5-fluorouracil by up-regulating MDR1 expression epigenetically
}

\author{
Li-liang Xia ${ }^{1,4, *}$, Ya-bin Tang ${ }^{2, *}$, Fei-fei Song ${ }^{2}$, Ling $X \mathbf{u}^{2}$, Ping $\mathrm{Ji}^{2}$, Shu-jun Wang ${ }^{2}$, \\ Ji-min Zhu ${ }^{3}$, Yong Zhang', Guo-ping Zhao, ${ }^{1,4,5}$, Ying Wang ${ }^{2}$, Tao-tao Liu ${ }^{3}$ \\ ${ }^{1}$ State Key Laboratory of Genetic Engineering, Department of Microbiology, School of Life Sciences and Institute of Biomedical \\ Sciences, Fudan University, Shanghai, China \\ ${ }^{2}$ Shanghai Institute of Immunology, Department of Immunology and Microbiology, Department of Pharmacology and \\ Chemical Biology, Shanghai Jiaotong University School of Medicine, Shanghai, China \\ ${ }^{3}$ Department of Gastroenterology, Zhongshan Hospital, Fudan University, Shanghai, China \\ ${ }^{4}$ Shanghai-MOST Key Laboratory of Health and Disease Genomics, Chinese National Human Genome Center at Shanghai, \\ Shanghai, China \\ ${ }^{5}$ Department of Microbiology and Li Ka Shing Institute of Health Sciences, The Chinese University of Hong Kong, Prince of \\ Wales Hospital, Shatin, New Territories, Hong Kong SAR, China \\ *These authors have contributed equally to this work \\ Correspondence to: Tao-tao Liv, email: liu.taotao@zs-hospital.sh.cn \\ Li-liang Xia, email: liliangxia@126.com
}

Keywords: dCTP pyrophosphatase 1, chemoresistance to 5-fluorouracil, 5-methyl-dCTP, methylation, multidrug resistance 1 Received: March 31, 2016

Accepted: August 24, 2016

Published: September 06, 2016

\section{ABSTRACT}

Gastric cancer (GC) is among the most malignant cancers with high incidence and poor prognoses worldwide as well as in China. dCTP pyrophosphatase 1 (DCTPP1) is overexpressed in GC with a poor prognosis. Given chemotherapeutic drugs share similar structures with pyrimidine nucleotides, the role of DCTPP1 in affecting the drug sensitivity in GC remains unclear and is worthy of investigation. In the present study, we reported that DCTPP1-knockdown GC cell line BGC-823 exhibited more sensitivity to 5-fluorouracil (5-FU), demonstrated by the retardation of cell proliferation, the increase in cell apoptosis, cell cycle arrest at $\mathbf{S}$ phase and more DNA damages. Multidrug resistance 1 (MDR1) expression was unexpectedly down-regulated in DCTPP1-knockdown BGC-823 cells together with more intracellular 5-FU accumulation. This was in large achieved by the elevated methylation in promoter region of MDR1 gene. The intracellular 5-methyl-dCTP level increased in DCTPP1-knockdown BGC-823 cells as well. More significantly, the strong correlation of DCTPP1 and MDR1 expression was detectable in clinical GC samples. Our results thus imply a novel mechanism of chemoresistance mediated by the overexpression of DCTPP1 in GC. It is achieved partially through decreasing the concentration of intracellular 5-methyl-dCTP, which in turn results in promoter hypomethylation and hyper-expression of drug resistant gene MDR1. Our study suggests DCTPP1 as a potential indicative biomarker for the predication of chemoresistance in GC.

\section{INTRODUCTION}

Gastric cancer (GC) is of great threat to human worldwide due to its high incidence and mortality among cancers $[1,2]$. In China, GC is identified as the second leading cause of cancer death [3]. Palliative chemotherapy is critical for GC treatment since most of GC patients are initially diagnosed at an advanced stage when surgical resection is not viable [4]. However, the overall benefits of chemotherapy are limited due to drug resistance during treatment [5]. Therefore, to identify new targets involved in drug resistance may foster opportunities to develop new strategies for the improvement of chemotherapy against GC.

Nucleoside triphosphate pyrophosphatases (NTPPPases) belong to nuclease family that are capable of hydrolyzing $\alpha-\beta$ phosphodiester bond of (d)NTPs into 
corresponding monophosphate and pyrophosphoric acid (PPi) [6]. To date, an array of NTP-PPases targeting non-canonical nucleotides have been identified from prokaryotes to mammalians. They are demonstrated to guarantee genome stability through preventing aberrant incorporation of non-canonical nucleotides into doublestrand DNA during replication, exerting "house-cleaning" function $[6,7]$. For example, MutT specifically catalyzes oxidative non-canonical nucleotides, such as 8-oxodGTP and 8-oxo-GTP, and prevents AT to CG mutation in Escherichia coli $[8,9]$. MazG from Mycobacterium tuberculosis can safeguard genetic stability via degrading 5-OH-dCTP [10]. Certain NTP-PPases are identified in mammalians with similar biological functions, such as dUTPase [11], ITPase [12] and MTH1 [13, 14]. Moreover, dUTPase and MTH1 are reported to be associated with carcinogenesis and tumor progression [15-18], potentiating their significance in clinic $[16,19,20]$.

dCTP pyrophosphatase 1 (DCTPP1) is an NTP-

PPase newly identified in human whose structure contains a bacterial MazG domain [21]. It hydrolyses dCTP, 5-methyl-dCTP and 5-halo-dCTPs with specificity whereas different efficacy $[21,22]$. Functional study indicates that DCTPP1 preserves genome integrity through degrading the non-canonical deoxycytidine analogues, such as 5-iodo-2'-deoxycytidine and 5-methyl-2'-deoxycytidine [22]. Our previous study showed that DCTPP1 was highly expressed in multiple carcinomas and exhibited nucleic accumulation in cancer cells, including GC [23]. What's more, high expression of DCTPP1 was strongly correlated with a poor prognosis in breast cancer [21] and GC [24]. DCTPP1 was involved in promoting cell proliferation of MCF-7 cells largely through controlling 5-methyl-dCTP metabolism and global DNA hypomethylation [21]. These results highlight the roles of DCTPP1 in cancer progression.

It is previously reported that the putative DCTPP1 inhibitors enhance the cytotoxicity against leukemia cells, including 5-azacytidine, decitabine, and gemcitabine [25]. Considering the structure similarity of chemotherapy drugs to dCTP nucleotides, the role of DCTPP1 in chemotherapy is worthy of exploration. In the present study, we investigated the effects of DCTPP1 on drug resistance to 5-FU in GC-derived cell line BGC-823 cells and further explored the underlying mechanisms.

\section{RESULTS}

\section{Knockdown of DCTPP1 increases drug sensitivity to 5-FU in BGC-823 cells}

To elucidate the roles of DCTPP1 in chemoresistance, we successfully established two DCTPP1 stable knockdown BGC-823 cells (BGC-823-shRNA1 and BGC-823shRNA2) by transfecting vectors containing short hairpin RNA (shRNA) specific to DCTPP1 (Table 1). DCTPP1 expression dramatically decreased at both mRNA and protein levels (Figure 1A and 1B). Although knockdown of DCTPP 1 had no impact on the proliferation of BGC-823 cells in vitro (Figure $1 \mathrm{C}$ ), it increased the sensitivity of both BGC-823-shRNA1 and BGC-823-shRNA2 cells to 5-FU in vitro with significant decrease in $\mathrm{IC}_{50(72 \mathrm{~h})}$ of 5-FU when compared to BGC-823-NC cells (Figure 1D). The increased sensitivity to 5-FU induced by DCTPP1 knockdown could be partially rescued by transient expression of DCTPP1 in DCTPP1-knockdown BGC-823 cells (Figure 1E and $1 F)$. In mouse xenograft experiments, tumor growth of BGC-823-shRNA1 was dramatically slower than that of BGC-823-NC in BALB/c nude mice after 5-FU treatment (Figure $1 \mathrm{G}$ to $1 \mathrm{I}$ ). Therefore, our results indicate that knockdown of DCTPP1 increases the sensitivity to 5-FU in BGC-823 cells both in vitro and in vivo.

\section{Knockdown of DCTPP1 induces more apoptosis in BGC-823 cells upon 5-FU treatment}

Apoptosis is one of the major mechanisms responsible for cell death induced by 5-FU [26]. To investigate the effect of DCTPP1 knockdown on apoptosis, BGC-823 cells were treated with $100 \mu \mathrm{M} 5$-FU for $48 \mathrm{~h}$ and the apoptotic cells were probed by using dual staining with PI and Annexin V (Figure 2A). The results indicated that upon 5-FU treatment the apoptotic rates of BGC823 -shRNA1 $(69.67 \% \pm 4.56 \%)$ and BGC-823-shRNA2 $(46.85 \% \pm 1.06 \%)$ cells were remarkably higher than that of BGC-823-NC cells $(13.07 \% \pm 0.72 \%)(P<0.001)$ (Figure 2B). More cleavage caspased-3 was detectable in BGC-823shRNA1 and BGC-823-shRNA2 cells (Figure 2C). These results support that knockdown of DCTPP1 promotes the apoptosis of BGC-823 cells induced by 5-FU in vitro.

\section{Knockdown of DCTPP1 arrests cell cycle of BGC-823 cells at S-phase after 5-FU treatment}

Cell cycle arrest is another major mechanism of proliferation impairment in cancer cells induced by $5-\mathrm{FU}$ [26]. To evaluate the effect of DCTPP1 on cell cycle arrest, we detected the cell cycle distribution of BGC823 cells treated with or without $1 \mu \mathrm{M} 5$-FU for $48 \mathrm{~h}$. Knockdown of DCTPP1 alone had little effect on cell cycle arrest in BGC-823 cells, which was consistent with the results from proliferation assay (Figure 1C). However, more BGC-823-shRNA1 $(65.11 \% \pm 2.32 \%)$ and BGC-823-shRNA2 $(60.85 \% \pm 1.51 \%)$ cells were observed arresting at S-phase than BGC-823-NC cells $(31.56 \% \pm$ $1.73 \%)$ after 5 -FU treatment $(P<0.001)$ (Figure $3 \mathrm{~A})$. The increase of cell population in S-phase was accompanied by a concomitant reduction in $\mathrm{G} 0 / \mathrm{G} 1$ and $\mathrm{G} 2 / \mathrm{M}$ phases in DCTPP1-knockdown BGC-823 cells (Figure 3B). These findings indicate that knockdown of DCTPP1 leads to more S-phase arrests upon 5-FU treatment in BGC-823 cells. 
Table 1: Oligonucleotides used in the study

\begin{tabular}{|c|c|c|}
\hline Name & Sequence & Purpose \\
\hline$D C T P P 1$ forward & 5'-CGCCTCCATGCTGAGTTTG-3' & \multirow{2}{*}{ Real-time PCR } \\
\hline$D C T P P 1$ reverse & 5'-CCAGGTTCCCCATCGGTTTTC-3' & \\
\hline$M D R 1$ forward & 5'-TGCGACAGGAGATAGGCTG-3' & \multirow{2}{*}{ Real-time PCR } \\
\hline$M D R 1$ reverse & 5'-GCCAAAATCACAAGGGTTAGCTT-3' & \\
\hline$G A P D H$ forward & 5'-AAGGTGAAGGTCGGAGTCAAC-3' & \multirow{2}{*}{ Real-time PCR } \\
\hline GAPDH reverse & 5'-GGGGTCATTGATGGCAACAATA-3' & \\
\hline DCTPP1-F Primer & 5'-CCCGGATCCATGTCTGTGGCCGG-3' & \multirow{2}{*}{ cDNA amplication } \\
\hline$D C T P P 1-\mathrm{R}$ Primer & 5'-CCCAAGCTTCTAGGTTGAGGTCTG-3' & \\
\hline MDR1-BSP-F & 5'-TGTAACGGAAGTTAGAATATTTTTTTTGG-3' & \multirow{2}{*}{ Bisulfite sequencing PCR } \\
\hline$M D R 1-\mathrm{BSP}-\mathrm{R}$ & 5'-AACTATCCCATAATAACTCCCAACTTTAC-3' & \\
\hline shRNA1 sense & $\begin{array}{c}\text { 5'-GATCCGCCCTTCAAGAGGAGCTTATTCAAGA } \\
\text { GATAAGCTCCTCTTGAAGGGCTTTTTTACGCGTG-3' }\end{array}$ & \multirow{2}{*}{ DCTPP1 Knockdown } \\
\hline shRNA1 antisense & $\begin{array}{l}\text { 5'-AATTCACGCGTAAAAAAGCCCTTCAGAGGAG } \\
\text { CTTATCTCTTGAAGCTCCTCTTGAAGGGCG-3' }\end{array}$ & \\
\hline shRNA2 sense & $\begin{array}{l}\text { 5'-GATCCGCCGCAAGTATACAGAATTGTTCAA } \\
\text { GAGACAATTCTGTATACTTGCGGTTTTTTACGCGTG-3' }\end{array}$ & \multirow{2}{*}{ DCTPP1 Knockdown } \\
\hline shRNA2 antisense & $\begin{array}{l}\text { 5'-AATTCACGCGTAAAAAACCGCAAGTATACA } \\
\text { GAATTGTCTCTTGAACAATTCTGTATACTTGCGGCG-3' }\end{array}$ & \\
\hline NC-sense & $\begin{array}{c}\text { 5'-GATCCGTGCGTTGCTAGTACCAACTTCAAG } \\
\text { AGATTTTTTACGCGTG-3' }\end{array}$ & \multirow{2}{*}{ Negative Control } \\
\hline NC-antisense & $\begin{array}{c}\text { 5'-AATTCCACGCGTAAAAAATCTCTTGAAGTTG } \\
\text { GTACTAGCAACGCACG-3' }\end{array}$ & \\
\hline
\end{tabular}

\section{Knockdown of DCTPP1 in BGC-823 cells increases DNA damage when treated with 5-FU}

5-FU is a fluoropyrimidine agent whose metabolites can induce DNA damage through incorporation into DNA during replication [27]. To examine the effect of DCTPP1 on DNA damage, response biomarkers for DNA damage, such as $\gamma$-H2AX and phospho-BRCA1 (Ser1524) were determined by Western blot in BGC-823 cells after 5-FU treatment for $24 \mathrm{~h}$. It was found that 5-FU treatment induced more $\gamma-\mathrm{H} 2 \mathrm{AX}$ and phospho-BRCA1 in BGC823-shRNA1 and BGC-823-shRNA2 cells than in BGC823-NC cells in a dose-dependent manner (Figure 4A). AP site is a location in DNA that has neither a purine nor a pyrimidine base due to DNA damage [28]. 5-FU treatment causes the incorporation of uracil into DNA strands, leading to the formation of AP sites during base excision repair [29]. DNA damage caused by 5-FU was further compared by counting AP sites in BGC-823 cells. Our results showed that contrary to the comparable number of AP sites between DCTPPl-knockdown and control BGC-823 cells without 5-FU treatment, more AP sites were detected in two DCTPP1-knockdown BGC-823 cells than control cells after 5-FU treatment even at low concentrations (Figure 4B). These results demonstrate that knockdown of DCTPP1 triggers more DNA damages in BGC-823 cells as well when treated with 5-FU.

\section{Apoptosis and 5-FU metabolism related gene expressions have no significant changes in DCTPP1-knockdown BGC-823 cells}

Considering the increase of apoptosis in DCTPP1knockdown BGC-823 cells induced by 5-FU, we measured the mRNA levels of apoptosis-associated genes $[30,31]$ by real-time PCR, including pro-apoptotic (Bax, $\mathrm{Bak}, \mathrm{Bad}, \mathrm{Bim}$ and $\mathrm{Bid})$ and anti-apoptotic genes ( $\mathrm{Bcl}$ 2, Mcl-1 and Survivin) (primer sequences were listed in Supplementary Table S1). However, no significant changes were observed in apoptosis-associated genes between DCTPP1-knockdown and control BGC-823 cells (Figure 5A). We further chose Bax and Bcl-2 to measure their protein levels by Western blot, and found that the expressions of Bax and Bcl-2 had no significant changes after DCTPP1 knockdown in BGC-823 cells (Figure 5C). 
Drug metabolism [27] is another mechanism responsible for drug resistance. Dihydropyrimidine dehydrogenase (DPD), orotate phosphoribosyltransferase (OPRT) and thymidylate synthase (TS) are enzymes that play key roles in 5-FU metabolism as well as drug resistance in carcinoma cells [32]. But the mRNA levels of $D P D, O P R T$ and $T S$ had no change in DCTPP1-knockdown BGC-823 cells either (Figure 5B). These results exclude the most common two possibilities for drug resistance.

\section{MDR1 expression is downregulated in DCTPP1- knockdown BGC-823 cells}

P-glycoprotein (P-gp) is a classical protein responsible for multi-drug resistance [33]. It is encoded by multidrug resistance 1 (MDR1) and functions as an ATP-dependent drug efflux pump that reduces intracellular concentrations of chemotherapeutic agents including 5-FU [34]. Therefore, we measured
A

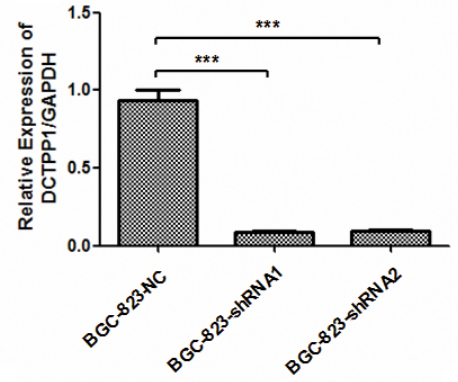

D

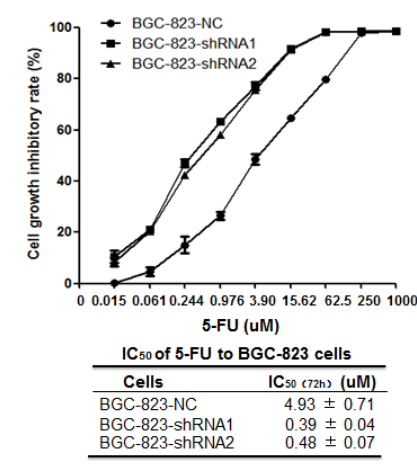

$\mathbf{G}$

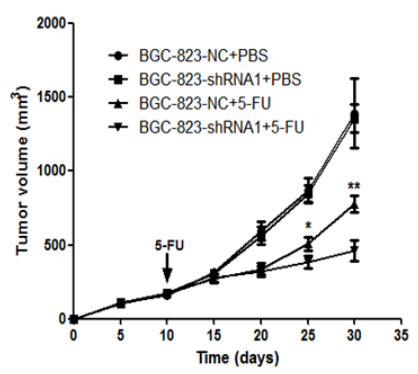

B

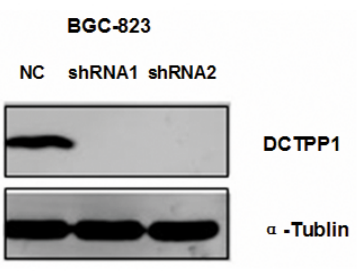

$\mathbf{E}$

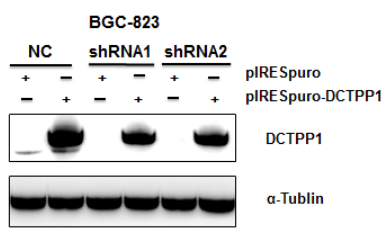

$\mathbf{H}$

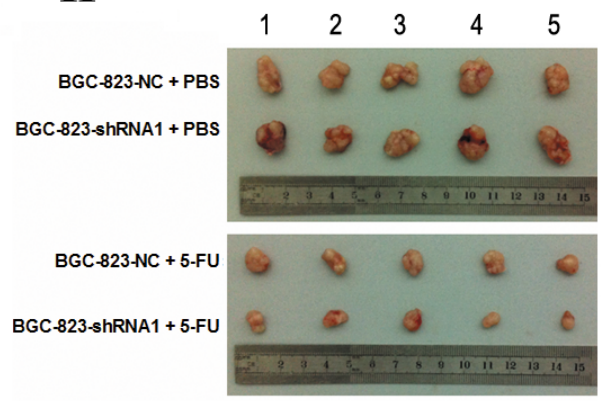

C

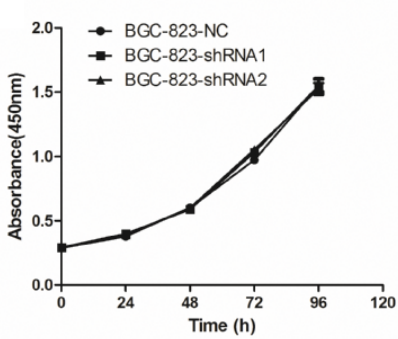

$\mathbf{F}$
I

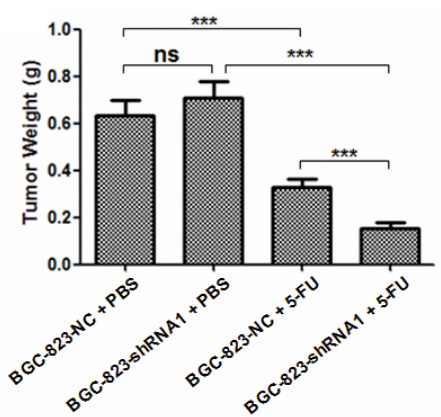

Figure 1: DCTPP1 knockdown in BGC-823 cells and its effects on cell proliferation upon 5-FU treatment. A. DCTPP1 expressions in DCTPP1-knockdown and control BGC-823 cells were determined by real-time PCR with GAPDH as an internal reference. B. DCTPP1 expressions in BGC-823 cells were determined by Western blot. C. In vitro cell proliferation curves of DCTPPI-knockdown and control BGC-823 cells detected by CCK-8 assay. D. Upper: cell proliferation inhibitory curves of DCTPP1-knockdown and control BGC-823 cells upon 5-FU treatment. Lower: $\mathrm{IC}_{50}$ values of DCTPP1-knockdown and control BGC-823 cells upon 5-FU treatment for $72 \mathrm{~h}$ in vitro. E. DCTPP1 expression was determined by Western blot analysis in BGC-823-NC, BGC-823-shRNA1 and BGC-823-shRNA2 cells

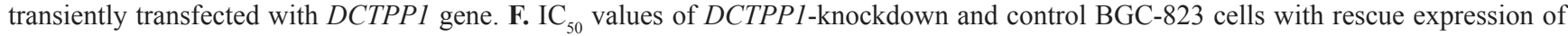
DCTPP1 upon 5-FU treatment for $72 \mathrm{~h}$. G. Tumor growth curves of BGC-823 cells in nude mice. Nude mice were injected subcutaneously with $3 \times 10^{6}$ cells/mouse. When the volumes of tumors reached $180-200 \mathrm{~mm}^{3}$, the mice were intraperitoneally injected with 5 -FU $(25 \mathrm{mg} /$ $\mathrm{kg})$ or PBS. Tumor volumes were measured every five days for 4 weeks $(\mathrm{n}=5)$. H. Xenograft tumors were stripped from nude mice and imaged. I. Tumor weights were assessed after sacrifice ( $\mathrm{n}=5$ in each group). All the values shown were represented as means $\pm \mathrm{SD}$. (ns: not significant; *: $P<0.05 ; * *: P<0.01 ; * * *: P<0.001$ vs control by two-tailed Student's $t$-test). 
the MDRI expression in DCTPP1-knockdown and control BGC-823 cells. It was shown that both the mRNA and protein levels of MDR1 significantly decreased in DCTPP1-knockdown BGC-823 cells when compared to control cells (Figure 6A and 6B). PSC833, a P-gp specific inhibitor [35], was used to verify the involvement of MDR1 in the chemosensitivity to 5-FU in BGC-823 cells. PSC833 together with 5-FU treatment significantly slowed down the proliferation of BGC-823-NC cells with high MDR1 expression in a dose-dependent manner. However no effect was observed in BGC-823-shRNA cells with lower MDR1 expression (Figure 6C). Moreover, LC-MS/MS assay showed that the intracellular 5-FU levels in DCTPP1knockdown BGC-823 cells were significantly higher than that in BGC-823 control cells when treated with $100 \mu \mathrm{M} 5$-FU for $1 \mathrm{~h}$ (Figure 6D). Our results thus indicate that the expression of MDR 1 is downregulated in DCTPP 1 -knockdown BGC-823 cells associated with the increased intracellular 5-FU accumulation, which probably dedicates to the increased chemosensitivity to 5-FU observed in DCTPP1-knockdown BGC-823 cells.
A

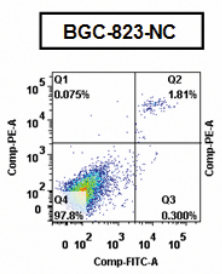

+5-FU

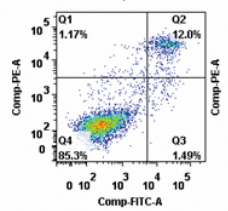

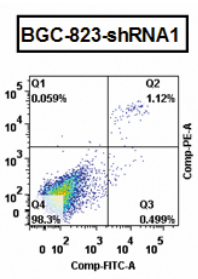

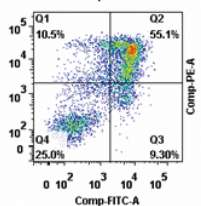

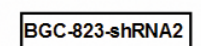
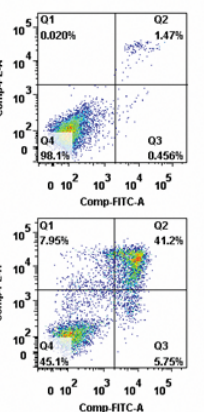

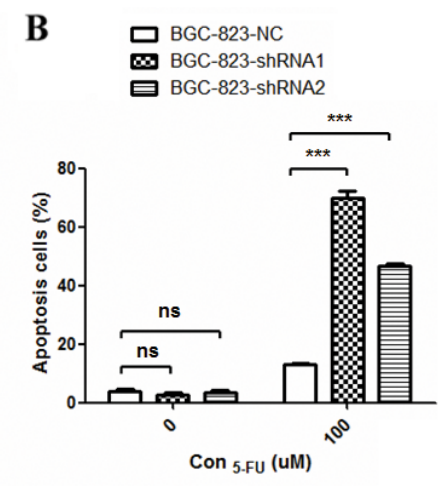

C

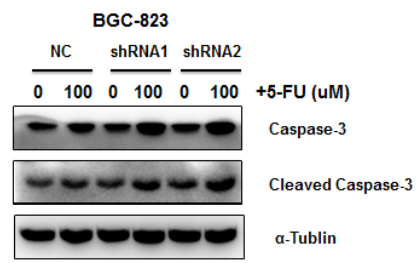

Figure 2: Effects of DCTPP1 knockdown on 5-FU-induced apoptosis in BGC-823 cells. A. Cells were treated with or without $100 \mu \mathrm{M} 5$-FU for $48 \mathrm{~h}$ and apoptosis was examined by using FITC-Annexin V/PI staining. The fluorescence intensity of FITC-Annexin $\mathrm{V}$ was plotted on the x-axis, and PI was plotted on the y-axis. FITC-PI-, FITC $/$ PI- $\mathrm{FITC}^{+} / \mathrm{PI}^{+}$, FITC-/PI ${ }^{+}$was regarded as living, early apoptotic, late apoptotic and necrotic cells, respectively. B. The statistical analysis of apoptotic BGC-823 cells (FITC ${ }^{+}$) with or without 5-FU treatment. C. Caspase-3 and cleavage caspase-3 levels in DCTPP1-knockdown and control BGC-823 cells upon 5-FU treatment were measured by Western blot. All the values shown were represented as means $\pm \mathrm{SD}$. (ns: not significant; $* * *: P<0.001$ vs control by two-tailed Student's $t$-test).

A
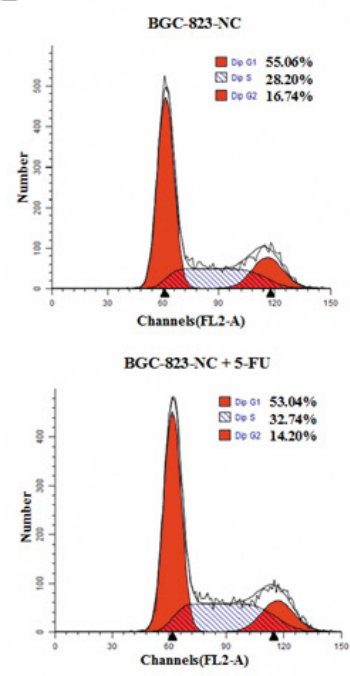
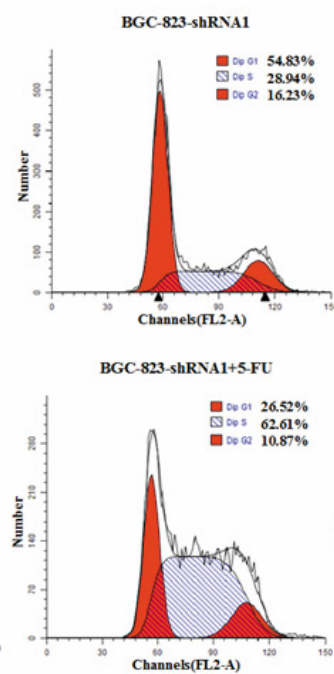
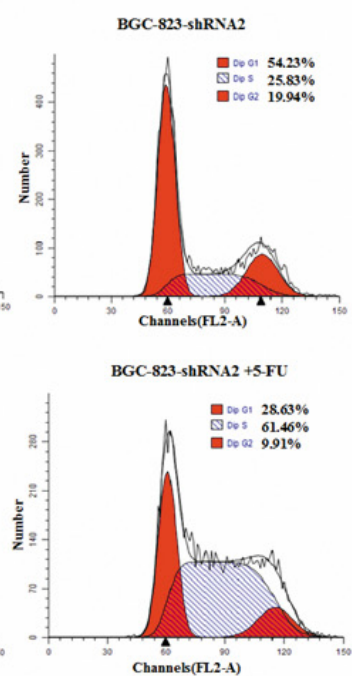

B

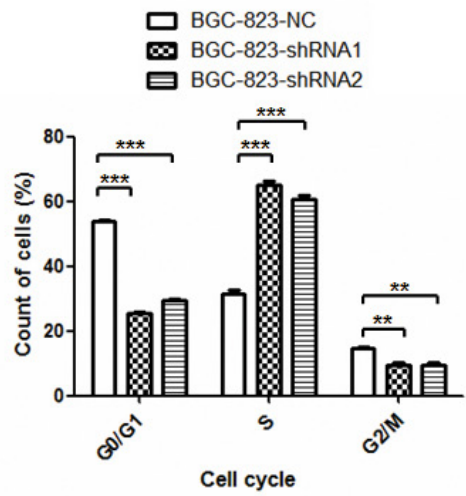

Figure 3: Effects of DCTPP1 knockdown on 5-FU-induced cell cycle arrest in BGC-823 cells. A. Cells were treated with or without $1 \mu \mathrm{M} 5$-FU for $48 \mathrm{~h}$. Cell cycle distribution was measured by using PI staining and flow cytometry analysis. One representative flow cytometric analysis of cell cycle distribution was shown. B. The statistical analysis of cell cycle distribution in BGC-823 cells upon 5-FU treatment. All the values shown were represented as means $\pm \mathrm{SD}$. (**: $P<0.01 ; * * *: P<0.001$ vs control by two-tailed Student's $t$-test). 


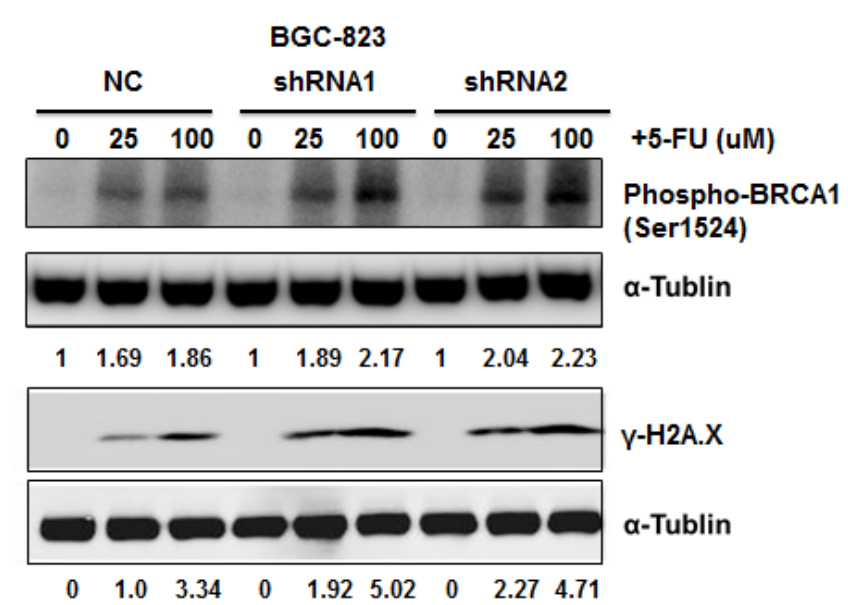

B

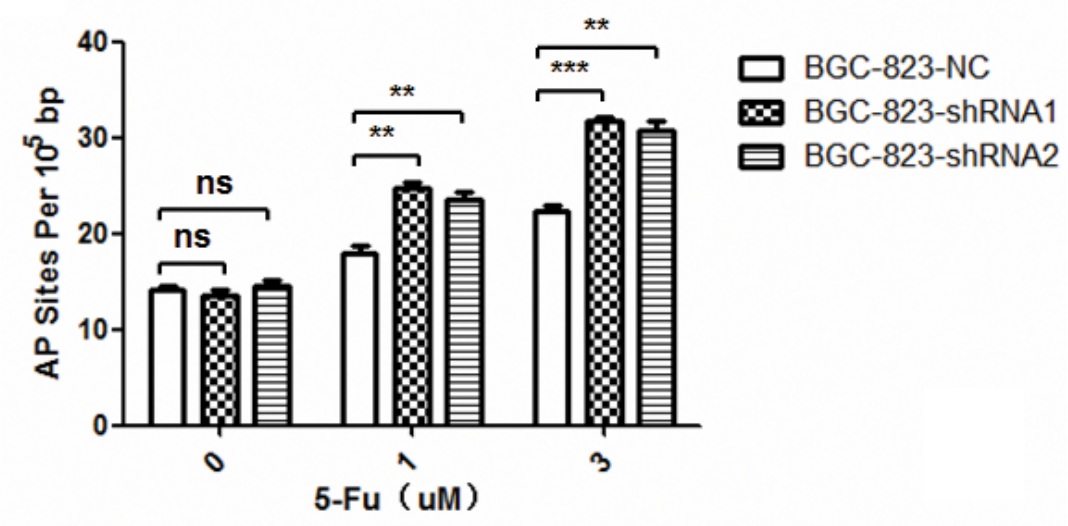

Figure 4: Effects of DCTPP1 knockdown on 5-FU-induced DNA damage in BGC-823 cells. A. DNA damage response biomarkers $\gamma$-H2AX and phospho-BRCA1 (Ser1524) were examined by Western blot in BGC-823 cells treated with 5-FU $(0,25,100 \mu \mathrm{M})$ for $24 \mathrm{~h}$. B. AP site levels were measured by DNA damage quantification kit in BGC-823 cells treated with 5-FU $(0,1,3 \mu \mathrm{M})$ for $48 \mathrm{~h}$. All the values shown were represented as means \pm SD. (ns: not significant; **: $P<0.01{ }^{* * *}: P<0.001$ vs control by two-tailed Student's $t$-test).
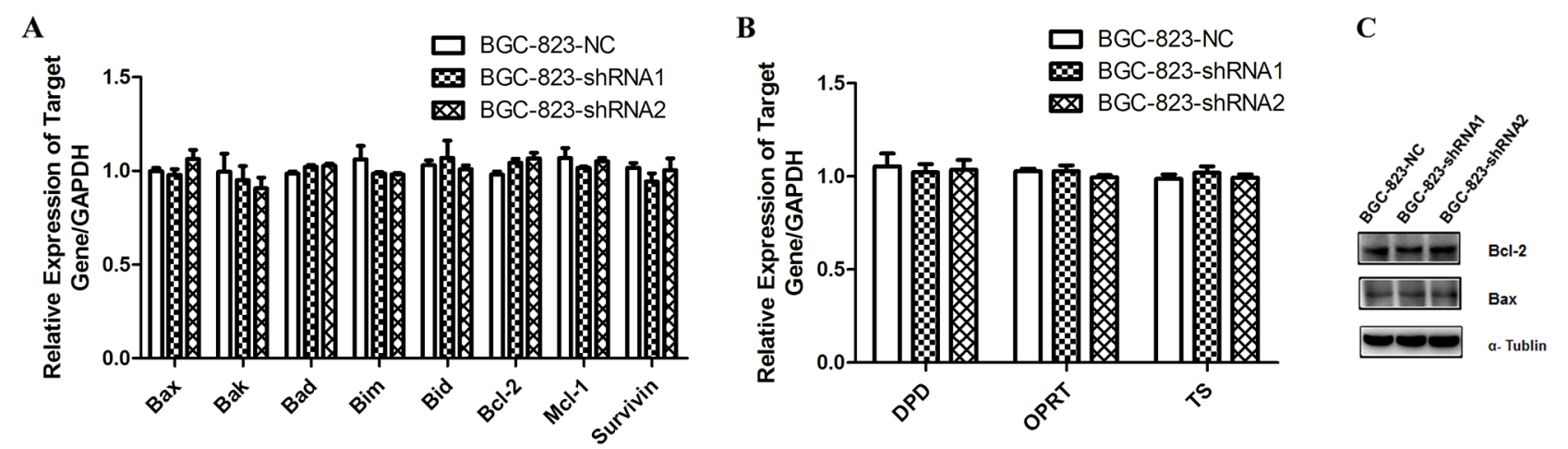

Figure 5: The expression of apoptosis-associated and 5-FU metabolism related genes in DCTPP1-knockdown and control BGC-823 cells. A. The mRNA levels of pro-apoptotic (Bax, Bak, Bad, Bim, Bid) and anti-apoptotic (Bcl-2, Mcl-1, Survivin) genes were determined in DCTPPI-knockdown and control BGC-823 cells by real-time PCR. B. The mRNA levels of 5-FU metabolism related enzymes $D P D, O P R T$ and $T S$ in $D C T P P 1$-knockdown and control BGC-823 cells were measured by real-time PCR. C. The protein levels of Bax and Bcl-2 in DCTPP1-knockdown and control BGC-823 cells were measured by Western blot. 


\section{Hypermethylation of $\mathrm{CpG}$ islands in MDR1 gene promoter region is obvious in DCTPP1- knockdown BGC-823 cells}

Epigenetic modification is one of the key mechanisms to regulate gene expression. Given the fact that down-regulation of MDRl is reported to be due to $\mathrm{CpG}$ hypermethylation in promoter region in certain cancers [36-38], we further compared the methylation in promoter region of $M D R 1$ gene between BGC-823-NC and BGC-823-shRNA cells. 20 $\mathrm{CpG}$ islands in $M D R 1$ gene promoter region were subjected to methylation analysis by using a bisulfite sequencing PCR approach. 10 clones for each $\mathrm{CpG}$ island were randomly selected for sequencing (Figure 7A). It was shown that the average methylation percentage of $\mathrm{CpG}$ islands in $M D R 1$ promoter region of BGC-823-NC cells was $26.5 \%$. However, those in BGC-823-shRNA1 and BGC-823-shRNA2 cells were $55.5 \%$ and $59.0 \%$, respectively, which was about 2 -fold higher than in BGC-823-NC cells (Figure 7B). This was remarkably consistent with the down-expression of $M D R 1$ in DCTPP1-knockdown BGC-823 cells.

\section{A}

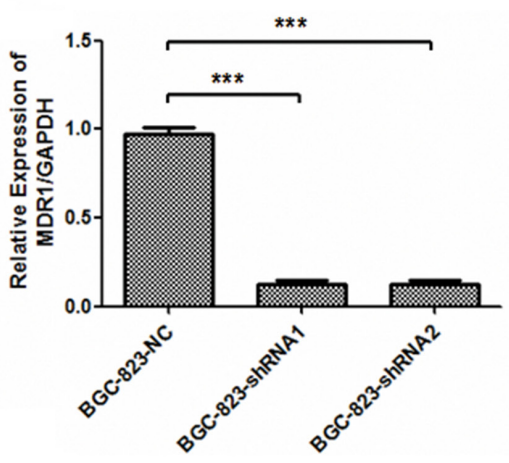

C

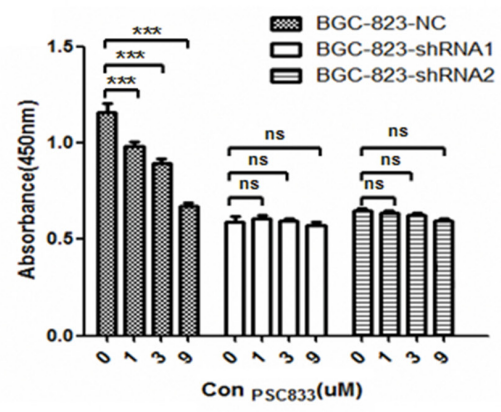

DCTPP1 knockdown leads to the increased intracellular concentration of 5-methyl-dCTP in BGC-823 cells

DCTPP1 hydrolyzes dCTP and its derivates, such as 5-methyl-dCTP, with different efficacy [21]. It was previously reported that the high concentration of intracellular 5-methyl-dCTP increased the incorporation into DNA leading to hypermethylation and downregulation of gene expression [39-41]. We further analyzed the effects of DCTPP1 on intracellular dCTP and 5-methyl-dCTP levels by LC-MS/MS assay. Contrary to the comparable concentrations of dCTP in DCTPP1knockdown and control BGC-823 cells (Figure 8B), the intracellular 5-methyl-dCTP levels increased significantly by two folds in DCTPP1-knockdown BGC-823 cells when compared to control cells (Figure 8A). We also measured the intracellular dTTP level, a key intermediate during intracellular metabolism of 5-FU. There were no obvious variations of dTTP levels in two types of BGC-823 cells either (Figure 8C).

B

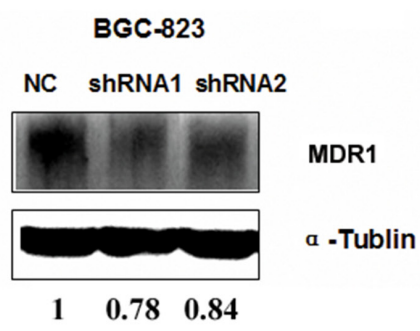

D

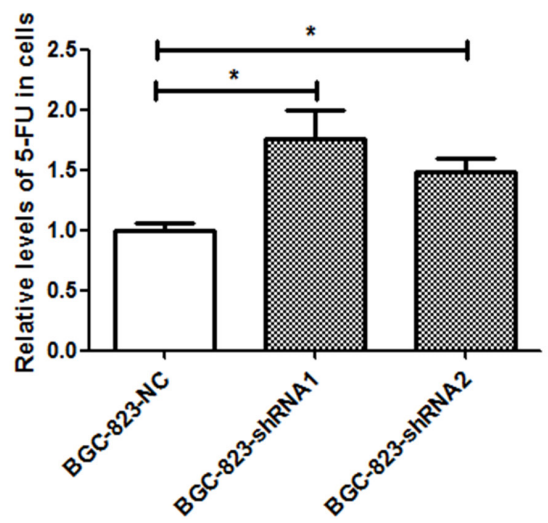

Figure 6: MDR1 expression in DCTPP1-knockdown BGC-823 cells. A. The mRNA level of $M D R 1$ was measured by real-time PCR in DCTPP1-knockdown and control BGC-823 cells. B. The protein level of MDR1 was measured by Western blot in DCTPP1knockdown and control BGC-823 cells. C. The effect of MDR1 on drug sensitivity to 5-FU in BGC-823 cells was tested by using MDR1 specific inhibitor PSC833. Cells were exposed to $2 \mu \mathrm{M}$ 5-FU combined with PSC833 $(0,1,3,9 \mu \mathrm{M})$ for $72 \mathrm{~h}$. Cell viability was detected by CCK-8 assay. D. The intracellular concentrations of 5-FU in DCTPP1-knockdown and control BGC-823 cells were measured by LC-MS/ MS assay. All the values shown were represented as means \pm SD. (ns: not significant; *: $P<0.05$; ***: $P<0.001$ vs control by two-tailed Student's $t$-test). 
DCTPP1 expression correlates strongly with MDR1 expression in gastric cancer tissues

Since our in vitro study indicated that DCTPP1 potentially influenced the expression of MDR1 in BGC823 cells, we further performed the association study between DCTPP1 and MDR1 expression in GC samples by using GC tissue microarray (Figure 9A). 30 gastric cancerous and paired adjacent regions were analyzed in parallel. It was found that the levels of DCTPP1 significantly correlated with MDR1 expression in GC tissues $(\mathrm{r}=0.621, P=0.0002)$ (Figure 9B), whereas no correlation was observed in adjacent tissues $(\mathrm{r}=0.338$, $P=0.068$ ) (Supplementary Figure S1). Interestingly, the correlation between DCTPP1 expression and MDR1 expression was more significant in GC samples with high tumor grade $(\mathrm{n}=14, \mathrm{r}=0.860, P<0.0001$, Figure 9C). These results thus provide clinical association of DCTPP1 and MDR1 co-expression, which partially supports the role of DCTPP1 in modulating MDR1 expression.

\section{DISCUSSION}

DCTPP1 is the only dCTP pyrophosphatase identified in human targeting $\mathrm{dCTP}$ and its structure derivates. Recently, its biological function and clinical significance have been illustrated $[21,22]$. In this study, we have investigated the effects of DCTPP1 on

A

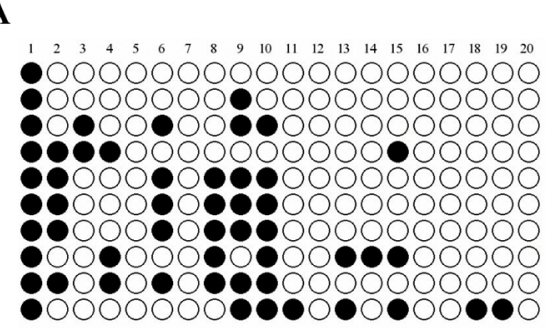

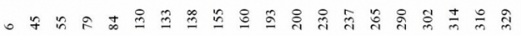

BGC-823-NC

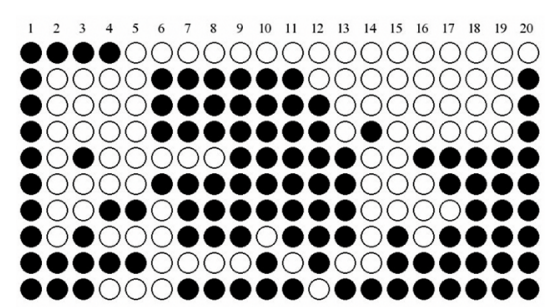

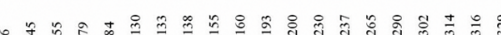

BGC-823-ShRNA1

B

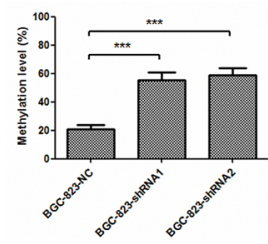

Figure 7: DNA methylation of $M D R 1$ promoter region in DCTPP1-knockdown and control BGC-823 cells. 20 CpG dinucleotides in MDR1 promoter region associated with MDR1 expression were selected for methylation analysis by bisulfite sequencing PCR. A. The methylation stature of 20 CpG dinucleotides in BGC-823-NC, BGC-823-shRNA1 and BGC-823-shRNA2 cells. "O" represented unmethylated $\mathrm{CpG}$ site and "•" for methylated CpG site. B. The statistical analysis of methylation levels in DCTPP1-knockdown and control BGC-823 cells. All the values shown were represented as means $\pm \mathrm{SD}$. (***: $P<0.001$ vs control by two-tailed Student's $t$-test).
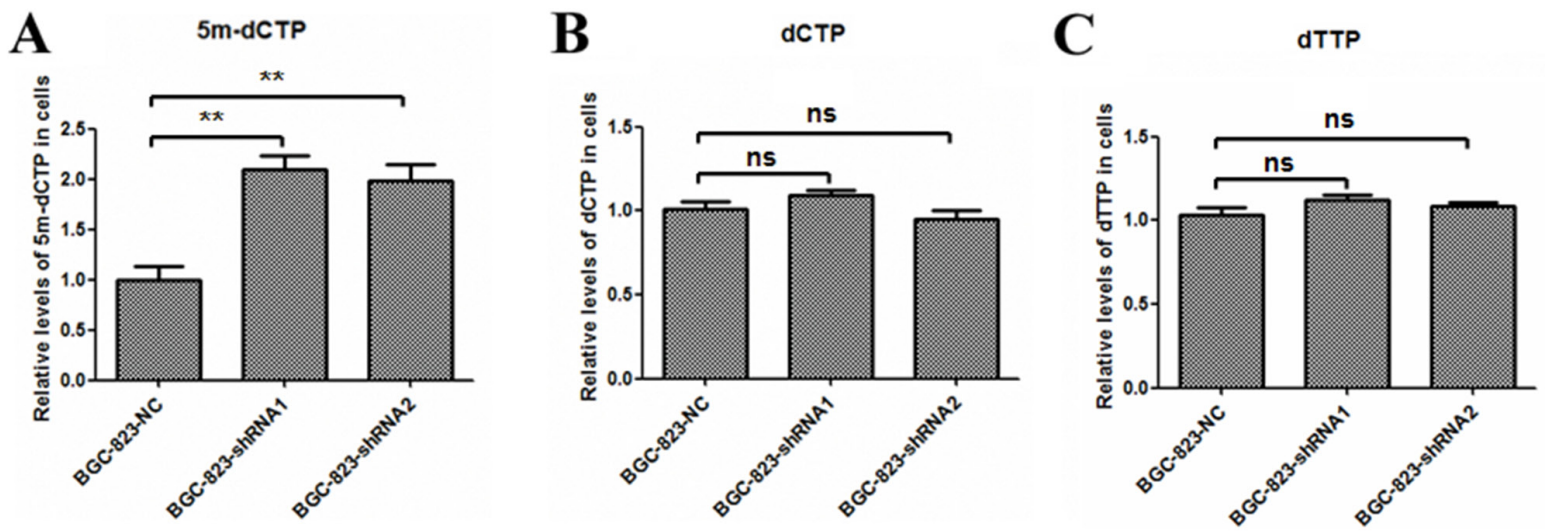

Figure 8: Intracellular 5-methyl-dCTP, dCTP and dTTP concentrations in DCTPP1-knockdown and control BGC-823 cells. The concentrations of A. 5-methyl-dCTP, B. dCTP, and C. dTTP in DCTPP1-knockdown and control BGC-823 cells were measured by LC-MS/ MS assay. All the values shown were represented as means \pm SD. (ns: not significant; **: $P<0.01$ vs control by two-tailed Student's $t$-test). 
chemoresistence to 5-FU. We found that knockdown of DCTPP1 significantly increased the sensitivity to 5-FU in GC cell line BGC-823 cells. Moreover, low expression of DCTPP1 led to the increase in intracellular 5 -methyl-dCTP, which was strongly associated with the promoter hyper-methylation, leading to the subsequent low-expression of $M D R 1$ and the increased intracellular accumulation of 5-FU in DCTPP1-knockdown BGC-823 cells. These results provide new insights into the roles of DCTPP1 as a chemosensitizer in clinical application.

5-FU is one of the first-line chemotherapeutic drugs against GC. However, the overall efficacy of 5-FU treatment is somehow limited in clinic due to drug resistance [27]. The molecular mechanisms of drug resistance are complex, involving anti-apoptosis [30, 31], drug metabolism [27], and drug transportation [42]. Our results showed that the expression of apoptosis-associated and 5-FU metabolism related genes had no significant changes between DCTPPl-knockdown and control
BGC-823 cells. These results impel us to focus on another conventional mechanism of drug resistance mediated by drug transportation.

The abnormal expressions of drug transporters, such as P-gp, multi-drug resistance protein 1 (MRP1) and mitoxantrone resistance protein (MXR/BCRP), are the major cause for chemotherapy failure [43]. Our results showed that $M R P 1$ and $M X R / B C R P$ had no significant changes between DCTPPl-knockdown and control BGC-823 cells (Supplementary Figure S2). But the expression of P-gp was downregulated in DCTPP1knockdown BGC-823 cells (Figure 6A and 6B). P-gp is a well-documented drug transporter. The increased expression of P-gp in GC has been reported to be associated with the poor prognosis and multidrug resistance $[44,45]$. P-gp is also reported to be involved in the drug resistance to 5-FU in BGC-823 cells [46, 47]. In this study, we illustrated that P-gp expression was downregulated in DCTPP1-knockdown BGC-823 cells
A
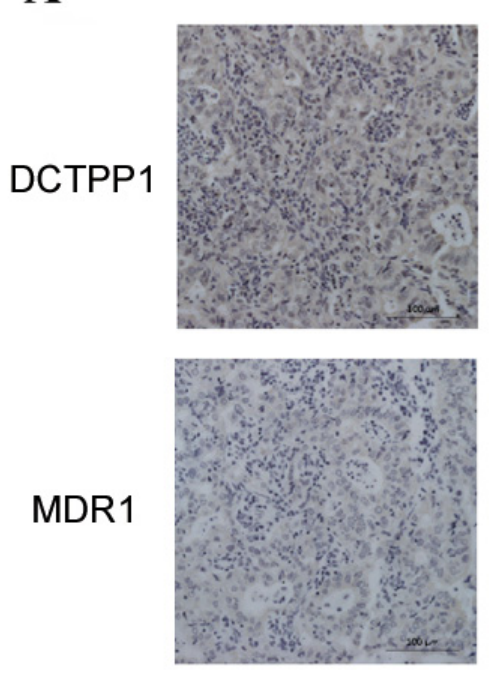

B

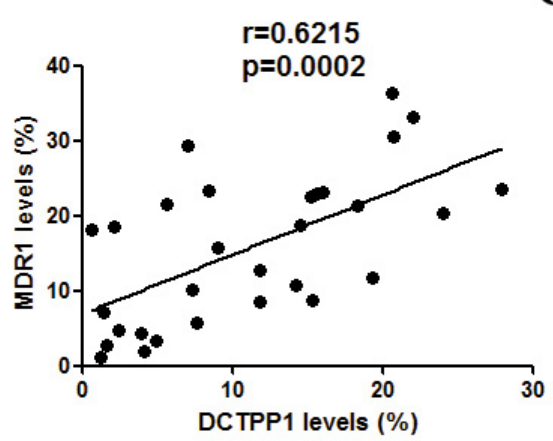

Case 2
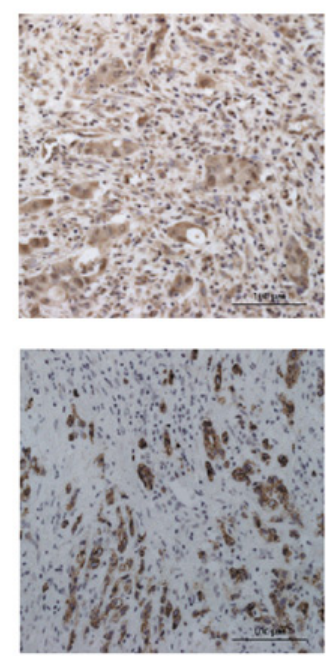

C

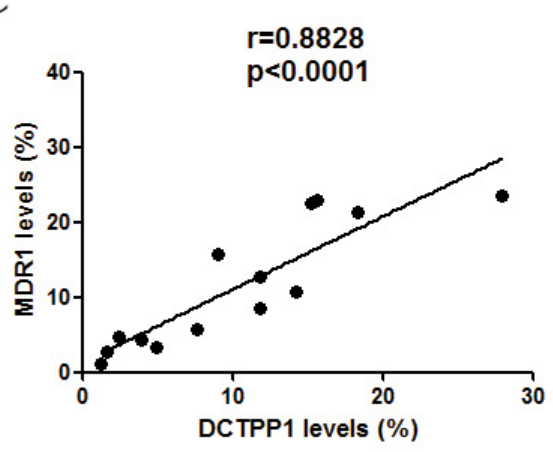

Figure 9: Correlation analysis of DCTPP1 and MDR1 expression in gastric cancer tissues. DCTPP1 and MDR1 expressions in GC samples were determined by immunohistochemical staining using commercial tissue microarrays. A. The representatives of low (case 1), middle (case 2) and high (case 3) expressions of DCTPP1 and MDR1 in GC tissues were shown. B. The correlation between DCTPP1 expression and MDR1 expression was analyzed in GC tissues $(n=30)$. Each dot presented one case. C. The correlation between DCTPP1 expression and MDR1 expression in GC tissues with high tumor grade (II-III and III grade, $\mathrm{n}=14$ ). The information of pathological grades was provided by tissue microarray commercial company. The correlation was calculated by using Pearson correlation coefficient. 
with more 5-FU accumulating in the cells (Figure 6D). This led to more cell apoptosis, cell cycle arrest as well as more DNA damage in DCTPP1-knockdown BGC-823 cells observed in our study.

How DCTPP1 knockdown affects MDR1 expression remains ambiguous. In some carcinomas, the $\mathrm{CpG}$ hypermethylation of MDR 1 promoter is thought to be one of the mechanisms causing down-regulation of $M D R 1$ [36, 48, 49]. Consistent with these findings, our results showed that the methylated $\mathrm{CpG}$ sites in MDRI promoter region significantly increased after DCTPP1 knockdown. It is well documented that DNA methylation is an enzyme-mediated post-replication process where DNA methyltransferase (DNMT) plays a critical role [50]. We compared the expression of DNMT family members between DCTPP1-knockdown and control BGC-823 cells. But the expressions of DNMT1, DNMT3A and DNMT3B had no significant difference before and after DCTPP1 knockdown in BGC-823 cells (Supplementary Figure S3), suggesting that other mechanism should be involved in regulating $\mathrm{CpG}$ hypermethylation in $M D R 1$ promoter region with DCTPP1 silencing.

5-methyl-dCTP is recognized as the fifth nucleotide in eukaryotic biology. It is reported previously that 5-methyl-dCTP is a nucleotide substrate of DNA polymerase and could be incorporated into DNA during replication [51]. What's more, the incorporation of 5-methyl-dCTP during DNA replication has been associated with DNA hypermethylation and gene silencing [39-41]. Therefore, the involvement of 5-methyl-dCTP in epigenetic modification highlights its significance in epigenetic inheritance. Our previous study showed that DCTPP1 could catalyze 5-methyl-dCTP preferentially in vitro. The intracellular 5-methyl-dCTP concentration increased in DCTPP1-knockdown breast cancer cell MCF7, suggesting 5-methyl-dCTP is one of the main substrates of DCTPP1 in cells [21]. Requena et al. have also revealed that DCTPP1-knockdown cells were hypersensitive to 5-methyl-2'-deoxycytidine, whose triphosphate form is 5-methyl-dCTP. Addition of 5-methyl-2'-deoxycytidine induced more increment in global DNA methylation in DCTPP1-knockdown cells than in control cells, supporting the function of DCTPP1 on down-regulating DNA methylation though preventing the incorporation of 5-methyl-dCTP into DNA strands [22]. In the present study, we also verified the increase of 5-methyl-dCTP in DCTPP1-knockdown BGC-823 cells, which is consistent with our previous study [21]. The increment of $\mathrm{CpG}$ methylation in $M D R 1$ promoter region was observed as well, which supports the function of DCTPP1 on DNA methylation through modulating the intracellular 5-methyl-dCTP concentration.

DCTPP1 is overexpressed in multiple cancers including GC. Its overexpression is correlated with a poor prognosis in GC [24], making it a potential diagnostic and therapeutic target in cancer therapy. Based on our findings from tissue microarrays, we defined the strong correlation between DCTPP1 and MDR1 expression, implying the involvement of DCTPP1 in drug sensitivity through modulating MDR1 expression during chemotherapy. Accordingly, we speculate that the intensive DCTPP1 expression may be a good biomarker for predicting the responses to certain chemotherapeutics, such as 5-FU. The association between DCTPP1 expression and clinical outcome of 5-FU treatment will be further evaluated in the future, which will provide direct evidence to support the roles of DCTPP1 in the enhancement of chemotherapy efficacy. Moreover, to develop DCTPP1 inhibitors may promote the efficacy of 5-FU in the treatment of certain GC patients.

In summary, we report here the engagement of DCTPP1 in increasing the chemoresistance of BGC-823 cells to 5-FU. This largely owes to the hypomethylation of MDR1 promoter region and the subsequent hyperexpression of protein, which in turn accelerates the efflux of intracellular 5-FU. DCTPP1 might be putatively a novel predicative biomarker for chemotherapy in the future.

\section{MATERIALS AND METHODS}

\section{Cell lines and reagents}

The GC cell line BGC-823 was purchased from the Shanghai Institute for Biological Sciences Chinese Academy of Sciences (Shanghai, China) and routinely maintained in DMEM medium (Gibco, Carlsbad, CA, USA) supplemented with $10 \%$ fetal bovine serum (FBS) (Gibco) in a $5 \% \mathrm{CO}_{2}$ humidified atmosphere at $37^{\circ} \mathrm{C}$.

Rabbit anti-human DCTPP1 polyclonal antibody (pAb) (Cat\#AP2821a) was obtained from Abgent (San Diego, USA). Mouse anti-human MDR1 (Cat\# sc55510) and mouse anti-DNMT1 monoclonal antibody (mAb) (Cat\# sc-271729) were purchased from Santa Cruz Biotechnology (Santa Cruz, CA, USA). Mouse anti$\alpha$-tublin Ab (Cat\# T6074) was purchased from Sigma (Louis, MO, USA). Rabbit anti-Phospho-BRCA1 Ab (Cat\# 9009), rabbit anti-Phospho-H2A.X Ab (Cat\# 2197), rabbit anti-caspase-3 (8G10) mAb (Cat\# 9665), rabbit anti-cleaved caspase-3 (Asp 175) mAb (Cat\# 9664), rabbit anti-Bax pAb (Cat\#2772), rabbit anti-Bcl-2 (50E3) mAb (Cat\# 2870), HRP-linked anti-rabbit IgG Ab (Cat\# 7074) and HRP-linked anti-mouse IgG Ab (Cat\# 7076) were purchased from Cell Signaling Technology (Beverly, MA, USA). dCTP, dTTP and 5-FU were purchased from Sigma and 5-methyl-dCTP was purchased from New England BioLabs (Ipswich, MA, USA).

\section{Construction of DCTPP1-knockdown BGC-823 cells}

Stable DCTPP1-knockdown BGC-823 cells were constructed by transfecting RNAi-Ready pSIRENRetroQ retroviral vector (Clontech, CA, USA) containing 
shRNA oligonucleotides targeting DCTPP1 as described in our previous report [21]. Briefly, BGC-823 cells were co-cultured with viral particles containing pSIRENRetroQ-shRNA1, pSIREN-RetroQ-shRNA2 or pSIRENRetroQ-negative control (NC) for $24 \mathrm{~h}$ (sequences of shRNA targeting DCTPPl and NC sequences were listed in Table 1 ). Complete DMEM medium containing 0.4 $\mu \mathrm{g} / \mathrm{mL}$ puromycin (Gibco) was replaced and cells were maintained for 1 week. Stably transfected cells were cultivated in complete DMEM medium with $0.2 \mu \mathrm{g}$ / $\mathrm{mL}$ puromycin for at least 1 week before proceeding for further study. The efficiency of RNA interference was determined by real-time PCR and Western blot analysis.

To rescue DCTPP1 in DCTPP1-knockdown BGC823 cells, DCTPP1 gene was amplified by PCR with the template from Hela cDNA (primer sequences were listed in Table 1 ) and inserted into pIRESpuro plasmid (Invitrogen) at the EcoRI and NotI sites. BGC-823 cells (4 $\times 10^{5} / 2 \mathrm{~mL}$ ) were seeded in 6 -well plates and transfected with recombinant plasmid pIRESpuro-DCTPP1 or empty vector using Lipofectamine 2000 (Invitrogen) according to the manufacturer's instructions. BGC-823 cells were trypsinized, counted and reseeded in 96-well plates for another $24 \mathrm{~h}$ after transfection. Cells were cultured with 5-FU (Sigma) at different concentrations (1000, 250, 62.5, $15.625,3.906,0.977,0.244,0.061,0.015,0 \mu \mathrm{M})$ for $72 \mathrm{~h}$ and subjected to cell viability assay.

\section{Cell viability assay in vitro}

Cells $\left(3 \times 10^{3} / 100 \mu \mathrm{L}\right)$ were seeded in 96-well plates (Corning, Steuben County, New York, USA). After 24 h, cells were cultured with 5-FU (Sigma) at different concentrations (1000, 250, 62.5, 15.625, 3.906, 0.977, 0.244, 0.061, 0.015, $0 \mu \mathrm{M}$ ) for $72 \mathrm{~h}$. Cell viability was analyzed afterwards by using CCK-8 kit (Dojindo Laboratories, Kumamoto, Japan) according to the manufacturer's instructions. The absorbance was measured at $450 \mathrm{~nm}$ on a microplate reader (BioRad, Hercules, CA, USA). $\mathrm{IC}_{50(72 \mathrm{~h})}$ value was calculated by GraphPad Prism 5 software (San Diego, CA, USA).

To investigate the roles of MDR1 in the chemosensitivity to 5-FU, BGC-823 cells were seeded in 96-well plates and treated with 5-FU and PSC833 (Medchemexpress, NJ, USA) for 72 hours. Cell viability was analyzed by using CCK-8 assay.

\section{Xenograft tumor growth in BALB/c-nu mice}

Six-week-old BALB/c nude mice (purchased from SLAC Company, Shanghai, China) were subcutaneously injected with $3 \times 10^{6}$ BGC-823-NC or BGC-823-shRNA1 cells. When the volumes of xenograft tumors reached 180 $200 \mathrm{~mm}^{3}$, mice were randomly subdivided into two groups with 5 mice in each group. Experimental groups were treated with 5 -FU intraperitoneally $(25 \mathrm{mg} / \mathrm{kg})$ at every other day for two weeks while control groups were treated with PBS. The volumes of xenograft tumors were measured by caliper and calculated by the following formula $\mathrm{V}=1 / 2 \times$ (length $\times$ width $\left.^{2}\right)$. After 4 weeks, nude mice were sacrificed and xenograft tumors were harvested and weighed. The protocols of animal experiments were approved by the Animal Ethics Committee of SJTUSM, and were performed under the Guide for the Care and Use of Laboratory Animals.

\section{Apoptosis analysis}

Cells $\left(1 \times 10^{5} / 2 \mathrm{~mL}\right)$ were seeded in 6-well plates and treated with or without $100 \mu \mathrm{M} 5$-FU. After incubation for $48 \mathrm{~h}$, total cells were harvested and washed twice with cold PBS. Cell apoptosis was analyzed by using FITC-Annexin V Apoptosis Detection Kit (Biolegend, San Diego, CA, USA) according to the manufacturer's instructions. Cells were acquired by FACS Calibur flow cytometer (BD Pharmingen, San Diego, CA, USA) and data analysis was performed by using FlowJo 7.6 software (Tree star, Ashland, Oregon, USA).

\section{Cell cycle analysis}

Cells $\left(1 \times 10^{5} / 2 \mathrm{~mL}\right)$ were seeded in 6 -well plates and treated with or without $1 \mu \mathrm{M} 5$-FU. After incubation for $48 \mathrm{~h}$, adherent cells were trypsinized, collected and washed twice with cold PBS. Cell pellets were resuspended in $5 \mathrm{~mL}$ ice-cold PBS containing $75 \%$ ethanol and fixed at $-20^{\circ} \mathrm{C}$ overnight. Cells were stained with PI/RNase staining buffer (BD Pharmingen, San Diego, CA, USA) according to DNA staining protocol for flow cytometry. Cells was acquired by FACS Calibur flow cytometer (BD Pharmingen ) and cell cycle was analyzed by ModFit software (Verity Software House, Topsham, ME, USA).

\section{DNA damage assay}

Cells $\left(1 \times 10^{5} / 2 \mathrm{~mL}\right)$ were seeded in 6 -well plates and treated with or without 5-FU. After incubation for 48 $\mathrm{h}$, adherent cells were collected. Proteins from some of the cells were extracted by RIPA lysis buffer. DNA damage markers, phospho-BRCA1 and phospho-H2A.X, were measured by Western blot. In addition, chromosomal DNA was extracted from part of the cultured cells. AP sites were measured using DNA Damage Quantification kit (Dojindo Laboratories) according to the manufacturer's instructions.

\section{Western blot}

Cells were washed twice with cold PBS, collected and lysed by RIPA lysis buffer containing $1 \mathrm{mM}$ phenylmethanesulfonyl fluoride (PSFM) (Beyotime, Nantong, Jiangsu, China). The whole cell extracts were collected and protein concentration was determined by BCA protein assay kit (BioRad, Hercules, CA, USA). Cell lysates were separated by $10 \%$ sodium dodecyl sulfate polyacrylamide gel electrophoresis (SDS-PAGE) and transferred to polyvinylidene difluoride (PVDF) membranes 
(Millipore Co., Billerica, MA, USA). The membranes were blocked with PBS (pH7.4) containing 5\% non-fat milk for $2 \mathrm{~h}$ at room temperature and then incubated with primary antibodies overnight at $4^{\circ} \mathrm{C}$. After incubation with HRPconjugated secondary antibodies for $1 \mathrm{~h}$, immunoreactive proteins were visualized with ECL detection system (Millipore Co.). Intensities of the bands were quantified by using an image analysis system (BioRad).

\section{Real-time PCR}

Total RNA was extracted with Trizol reagent (Invitrogen Life Technologies, Carlsbad, CA, USA) according to the manufacturer's instructions. First-strand cDNA was synthesized by using a PrimeScript ${ }^{\mathrm{TM}}$ RT reagent Kit with gDNA Eraser (Takara Biotechnology, Dalian, China). The primer sequences used in real-time PCR were listed in Table 1 and Supplementary Table S1. Real-time PCR was performed using applied biosystems 7300 real-time PCR system with SYBR ${ }^{\circledR}$ Premix Ex Taq ${ }^{\text {TM }}$ kits (Takara Biotechnology, Dalian, China) according to the manufacturer's instructions.

\section{Methylation analysis}

Total DNA was extracted from cultured cells using TaKaRa MiniBEST Universal Genomic DNA Extraction Kit (Takara Biotechnology). Bisulfite sequencing PCR (BSP) was performed in BioSun Biotech Co. Ltd. (Shanghai, China). Briefly, MDR1-BSP-F and MDR1-BSP-R primers were designed for the amplification of the promoter region of MDR 1 gene including $20 \mathrm{CpG}$ dinucleotides that have been reported to be highly linked to the regulation of $M D R 1$ expression [36-38]. The BSP was carried out in $50 \mu \mathrm{L}$ reaction system containing $0.2 \mathrm{mM}$ dNTPs, $2 \mathrm{mM} \mathrm{MgCl}$, $0.2 \mu \mathrm{M}$ primer, 12.5 units TaqHS (Takara Biotechnology), and $600 \mathrm{ng}$ bisulfite-modified DNA. The BSP conditions were $94^{\circ} \mathrm{C}$ for $1 \mathrm{~min}$, followed by 37 cycles at $94^{\circ} \mathrm{C}$ for 15 $\mathrm{s}, 54^{\circ} \mathrm{C}$ for $20 \mathrm{~s}$, and $72^{\circ} \mathrm{C}$ for $25 \mathrm{~s}$, with a final extension at $72^{\circ} \mathrm{C}$ for $10 \mathrm{~min}$. PCR products were purified and cloned into the pEASY-T1 vector for sequencing. For each PCR sample, 10 individual clones were randomly selected and sequenced in the experiments. In the BSP assay, the treatment of bisulfite led to the conversion of cytosine residues into uracil whereas 5-methyl-cytosine residues unaffected. After PCR amplification, original unmethylated cytosines were converted to thymine while methylated cytosines remained. Therefore, methylation level was determined according to the average methylation rate of 20 $\mathrm{CpG}$ dinucleotides for each DNA sample.

\section{Liquid chromatography tandem mass spectrometry (LC-MS/MS) assay}

Intracellular nucleotides were measured by LC-MS/ MS as described in our previous study [21] with minor modifications. Briefly, cells were harvested and washed twice with cold saline. $5 \times 10^{6}$ cells were extracted with $500 \mu \mathrm{L}$ pre-cold $60 \%$ methanol and immediately frozen in liquid nitrogen. After storage at $-80^{\circ} \mathrm{C}$ for at least 24 $\mathrm{h}$, sample solutions were centrifuged at $14,000 \mathrm{~g}$ for 10 $\min$ at $4^{\circ} \mathrm{C}$. The supernatants were collected and stored at $-80^{\circ} \mathrm{C}$ until for LC-MS/MS analysis.

Intracellular 5-FU was measured by LC-MS/MS as described in previous report [52] with minor modifications. Briefly, $1.5 \times 10^{6}$ BGC-823 cells were seeded in $10 \mathrm{~cm}$ dish overnight and treated with $10 \mathrm{~mL}$ DMEM medium containing $100 \mu \mathrm{M} 5$-FU. After incubation for $1 \mathrm{~h}$, the medium was replaced with $10 \mathrm{~mL}$ DMEM medium. After incubation for another $15 \mathrm{~min}$, the intracellular 5-FU was extracted by pre-cold $60 \%$ methanol as described above.

LC-MS/MS assay was performed using an Agilent 1200 HPLC system coupled to an Agilent 6410 triple quadruple mass spectrometer (Agilent Technologies, Palo Alto, CA, USA). The mode of multiple reaction monitoring (MRM) was used to identify and quantify dCTP (transition: $\mathrm{m} / \mathrm{z} 468.1[\mathrm{M}+\mathrm{H}]+\rightarrow$ 112.1, fragmentor $120 \mathrm{~V}$, collision energy $20 \mathrm{eV}$ ), 5-methyl-dCTP (transition: $\mathrm{m} / \mathrm{z} 482.1[\mathrm{M}+\mathrm{H}]+\rightarrow 126.1$, fragmentor 140 $\mathrm{V}$, collision energy $20 \mathrm{eV}$ ), dTTP (transition: $\mathrm{m} / \mathrm{z} 480.1$ $[\mathrm{M}+\mathrm{H}]+\rightarrow 159.1$, fragmentor $125 \mathrm{~V}$, collision energy $20 \mathrm{eV}$ ), and 5-FU (transition: $\mathrm{m} / \mathrm{z} 129[\mathrm{M}+\mathrm{H}]+\rightarrow 42.2$, declustering potential $-55 \mathrm{~V}$, collision energy $-25 \mathrm{eV}$ ). The data of peak areas were acquired and the relative quality of compound tested in BGC-823 cells was analyzed accordingly to their areas of peaks.

\section{Gastric cancer tissue microarray}

Tissue microarray containing 30 formalin-fixed, paraffin-embedded GC tissues and 30 paired adjacent tissues $(2.0 \mathrm{~mm}$ in diameter and $4 \mu \mathrm{m}$ in thickness) was purchased from the Shanghai Outdo Biotech Company (Shanghai, China). The expressions of DCTPP1 and MDR1 in GC tissue microarray were tested by immunohistochemistry described in our previous report using anti-DCTPP1 and anti-MDR1 antibodies [21]. Slides were observed under the light microscope and data were analyzed using the Leica Qwin V3 image analysis system (Leica Microsystems GmbH, Wetzlar, Germany). The extent of specific staining was calculated according to the percentage of positive area to the total area of campus visualis $(\times 100)$.

\section{Statistics analysis}

All the data were represented as the means \pm standard deviation (SD). Statistical analysis was carried out by using two-tailed Student's $t$-test with SPSS version 20.0 (SPSS Inc, Chicago, IL, USA). Differences between groups were determined as statistically significant at $P<0.05$. The correlation between DCTPP1 and MDR1 expression was assessed using Pearson correlation coefficient. $P<0.05$ was considered significant. 


\section{ACKNOWLEDGMENTS}

This work was supported by grants from National Natural Science Foundation of China (81602573), Shanghai Natural Science Foundation (14ZR1436300) and Shanghai Municipal Education Committee (13ZZ083).

\section{CONFLICTS OF INTEREST}

The authors declared no conflict of interest.

\section{REFERENCES}

1. Ferlay J, Soerjomataram I, Dikshit R, Eser S, Mathers C, Rebelo M, Parkin DM, Forman D and Bray F. Cancer incidence and mortality worldwide: sources, methods and major patterns in GLOBOCAN 2012. International journal of cancer. 2015; 136:E359-386.

2. Torre LA, Bray F, Siegel RL, Ferlay J, Lortet-Tieulent J and Jemal A. Global cancer statistics, 2012. CA Cancer J Clin. 2015; 65:87-108.

3. Chen W, Zheng R, Baade PD, Zhang S, Zeng H, Bray F, Jemal A, Yu XQ and He J. Cancer statistics in China, 2015. CA Cancer J Clin. 2016.

4. Karimi P, Islami F, Anandasabapathy S, Freedman ND and Kamangar F. Gastric cancer: descriptive epidemiology, risk factors, screening, and prevention. Cancer epidemiology, biomarkers \& prevention. 2014; 23:700-713.

5. Meta-analysis Group In C, Piedbois P, Rougier P, Buyse M, Pignon J, Ryan L, Hansen R, Zee B, Weinerman B, Pater J, Leichman C, Macdonald J, Benedetti J, Lokich J, Fryer J, Brufman G, et al. Efficacy of intravenous continuous infusion of fluorouracil compared with bolus administration in advanced colorectal cancer. Journal of clinical oncology. 1998; 16:301-308.

6. Moroz OV, Murzin AG, Makarova KS, Koonin EV, Wilson KS and Galperin MY. Dimeric dUTPases, HisE, and MazG belong to a new superfamily of all-alpha NTP pyrophosphohydrolases with potential "housecleaning" functions. Journal of molecular biology. 2005; 347:243-255.

7. Galperin MY, Moroz OV, Wilson KS and Murzin AG. House cleaning, a part of good housekeeping. Molecular microbiology. 2006; 59:5-19.

8. McLennan AG. The Nudix hydrolase superfamily. Cellular and molecular life sciences. 2006; 63:123-143.

9. Maki $\mathrm{H}$ and Sekiguchi M. MutT protein specifically hydrolyses a potent mutagenic substrate for DNA synthesis. Nature. 1992; 355:273-275.

10. Lyu LD, Tang BK, Fan XY, Ma H and Zhao GP. Mycobacterial MazG safeguards genetic stability via housecleaning of 5-OH-dCTP. PLoS pathogens. 2013; 9:e1003814.
11. Toth J, Varga B, Kovacs M, Malnasi-Csizmadia A and Vertessy BG. Kinetic mechanism of human dUTPase, an essential nucleotide pyrophosphatase enzyme. The Journal of biological chemistry. 2007; 282:33572-33582.

12. Menezes MR, Waisertreiger IS, Lopez-Bertoni H, Luo $\mathrm{X}$ and Pavlov YI. Pivotal role of inosine triphosphate pyrophosphatase in maintaining genome stability and the prevention of apoptosis in human cells. PloS one. 2012; 7:e32313.

13. Mishima M, Sakai Y, Itoh N, Kamiya H, Furuichi M, Takahashi M, Yamagata Y, Iwai S, Nakabeppu Y and Shirakawa M. Structure of human MTH1, a Nudix family hydrolase that selectively degrades oxidized purine nucleoside triphosphates. The Journal of biological chemistry. 2004; 279:33806-33815.

14. Nakabeppu Y, Oka S, Sheng Z, Tsuchimoto D and Sakumi K. Programmed cell death triggered by nucleotide pool damage and its prevention by MutT homolog-1 (MTH1) with oxidized purine nucleoside triphosphatase. Mutation research. 2010; 703:51-58.

15. Tsuzuki T, Egashira A and Kura S. Analysis of MTH1 gene function in mice with targeted mutagenesis. Mutation research. 2001; 477:71-78.

16. Gad H, Koolmeister T, Jemth AS, Eshtad S, Jacques SA, Strom CE, Svensson LM, Schultz N, Lundback T, Einarsdottir BO, Saleh A, Gokturk C, Baranczewski P, Svensson R, Berntsson RP, Gustafsson R, et al. MTH1 inhibition eradicates cancer by preventing sanitation of the dNTP pool. Nature. 2014; 508:215-221.

17. Ladner RD, Lynch FJ, Groshen S, Xiong YP, Sherrod A, Caradonna SJ, Stoehlmacher J and Lenz HJ. dUTP nucleotidohydrolase isoform expression in normal and neoplastic tissues: association with survival and response to 5-fluorouracil in colorectal cancer. Cancer research. 2000; 60:3493-3503.

18. Takatori H, Yamashita T, Honda M, Nishino R, Arai K, Yamashita T, Takamura H, Ohta T, Zen Y and Kaneko S. dUTP pyrophosphatase expression correlates with a poor prognosis in hepatocellular carcinoma. Liver international. 2010; 30:438-446.

19. Miyahara S, Miyakoshi H, Yokogawa T, Chong KT, Taguchi J, Muto T, Endoh K, Yano W, Wakasa T, Ueno H, Takao Y, Fujioka A, Hashimoto A, Itou K, Yamamura K, Nomura M, et al. Discovery of a novel class of potent human deoxyuridine triphosphatase inhibitors remarkably enhancing the antitumor activity of thymidylate synthase inhibitors. Journal of medicinal chemistry. 2012; 55:2970-2980.

20. Miyahara S, Miyakoshi H, Yokogawa T, Chong KT, Taguchi J, Muto T, Endoh K, Yano W, Wakasa T, Ueno H, Takao Y, Fujioka A, Hashimoto A, Itou K, Yamamura K, Nomura $\mathrm{M}$, et al. Discovery of highly potent human deoxyuridine triphosphatase inhibitors based on the conformation restriction strategy. Journal of medicinal chemistry. 2012; 55:5483-5496. 
21. Song FF, Xia LL, Ji P, Tang YB, Huang ZM, Zhu L, Zhang J, Wang JQ, Zhao GP, Ge HL, Zhang Y and Wang Y. Human dCTP pyrophosphatase 1 promotes breast cancer cell growth and stemness through the modulation on 5-methyl-dCTP metabolism and global hypomethylation. Oncogenesis. 2015; 4:e159.

22. Requena CE, Perez-Moreno G, Ruiz-Perez LM, Vidal AE and Gonzalez-Pacanowska D. The NTP pyrophosphatase DCTPP1 contributes to the homoeostasis and cleansing of the dNTP pool in human cells. The Biochemical journal. 2014; 459:171-180.

23. Zhang Y, Ye WY, Wang JQ, Wang SJ, Ji P, Zhou GY, Zhao GP, Ge HL and Wang Y. dCTP pyrophosphohydrase exhibits nucleic accumulation in multiple carcinomas. European journal of histochemistry. 2013; 57:e29.

24. Morisaki T, Yashiro M, Kakehashi A, Inagaki A, Kinoshita H, Fukuoka T, Kasashima H, Masuda G, Sakurai K, Kubo N, Muguruma K, Ohira M, Wanibuchi H and Hirakawa K. Comparative proteomics analysis of gastric cancer stem cells. PloS one. 2014; 9:e110736.

25. Llona-Minguez S, Hoglund A, Jacques SA, Johansson L, Calderon-Montano JM, Claesson M, Loseva O, Valerie NC, Lundback T, Piedrafita J, Maga G, Crespan E, Meijer L, Burgos Moron E, Baranczewski P, Hagbjork AL, et al. Discovery of the First Potent and Selective Inhibitors of Human dCTP Pyrophosphatase 1. Journal of medicinal chemistry. 2016; 59:1140-1148.

26. Sampath D, Rao VA and Plunkett W. Mechanisms of apoptosis induction by nucleoside analogs. Oncogene. 2003; 22:9063-9074.

27. Longley DB, Harkin DP and Johnston PG. 5-fluorouracil: mechanisms of action and clinical strategies. Nature reviews Cancer. 2003; 3:330-338.

28. Boiteux S and Guillet M. Abasic sites in DNA: repair and biological consequences in Saccharomyces cerevisiae. DNA repair. 2004; 3:1-12.

29. Seiple L, Jaruga P, Dizdaroglu M and Stivers JT. Linking uracil base excision repair and 5-fluorouracil toxicity in yeast. Nucleic acids research. 2006; 34:140-151.

30. Gao J, Yan Q, Liu S and Yang X. Knockdown of EpCAM enhances the chemosensitivity of breast cancer cells to 5-fluorouracil by downregulating the antiapoptotic factor Bcl-2. PloS one. 2014; 9:e102590.

31. Konishi T, Sasaki S, Watanabe T, Kitayama J and Nagawa H. Overexpression of hRFI inhibits 5-fluorouracilinduced apoptosis in colorectal cancer cells via activation of NF-kappaB and upregulation of BCL-2 and BCL-XL. Oncogene. 2006; 25:3160-3169.

32. Wang J, Liu W, Zhao Q, Qi Q, Lu N, Yang Y, Nei FF, Rong JJ, You QD and Guo QL. Synergistic effect of 5-fluorouracil with gambogic acid on BGC-823 human gastric carcinoma. Toxicology. 2009; 256:135-140.

33. Chen KG and Sikic BI. Molecular pathways: regulation and therapeutic implications of multidrug resistance. Clinical cancer research. 2012; 18:1863-1869.
34. Tang B, Zhang Y, Liang R, Gao Z, Sun D and Wang L. RNAi-mediated EZH2 depletion decreases MDR1 expression and sensitizes multidrug-resistant hepatocellular carcinoma cells to chemotherapy. Oncology reports. 2013; 29:1037-1042.

35. Jonsson B, Nilsson K, Nygren P and Larsson R. SDZ PSC833--a novel potent in vitro chemosensitizer in multiple myeloma. Anti-cancer drugs. 1992; 3:641-646.

36. Tada Y, Wada M, Kuroiwa K, Kinugawa N, Harada T, Nagayama J, Nakagawa M, Naito S and Kuwano M. MDR1 gene overexpression and altered degree of methylation at the promoter region in bladder cancer during chemotherapeutic treatment. Clinical cancer research. 2000; 6:4618-4627.

37. Tahara T, Arisawa T, Shibata T, Yamashita H, Yoshioka D and Hirata I. Effect of promoter methylation of multidrug resistance 1 (MDR1) gene in gastric carcinogenesis. Anticancer research. 2009; 29:337-341.

38. Garfield DH, Cadranel J and West HJ. Promoter methylation of glutathione S-transferase pil and multidrug resistance gene 1 in bronchioloalveolar carcinoma and its correlation with DNA methyltransferase 1 expression. Cancer. 2010; 116:1838; author reply 1839 .

39. Paulin RP, Ho T, Balzer HJ and Holliday R. Gene silencing by DNA methylation and dual inheritance in Chinese hamster ovary cells. Genetics. 1998; 149:1081-1088.

40. Holliday R and Ho T. Gene silencing and endogenous DNA methylation in mammalian cells. Mutation research. 1998; 400:361-368.

41. Nyce J. Gene silencing in mammalian cells by direct incorporation of electroporated 5-methyl-2'-deoxycytidine 5 '-triphosphate. Somatic cell and molecular genetics. 1991; 17:543-550.

42. Scotto KW. Transcriptional regulation of $\mathrm{ABC}$ drug transporters. Oncogene. 2003; 22:7496-7511.

43. Gottesman MM, Fojo T and Bates SE. Multidrug resistance in cancer: role of ATP-dependent transporters. Nature reviews Cancer. 2002; 2:48-58.

44. Zhang D and Fan D. Multidrug resistance in gastric cancer: recent research advances and ongoing therapeutic challenges. Expert review of anticancer therapy. 2007; 7:1369-1378.

45. Xu HW, Xu L, Hao JH, Qin CY and Liu H. Expression of P-glycoprotein and multidrug resistance-associated protein is associated with multidrug resistance in gastric cancer. The Journal of international medical research. 2010; 38:34-42.

46. Liu D, Zhou H, Wu J, Liu W, Li Y, Shi G, Yue X, Sun X, Zhao $\mathrm{Y}, \mathrm{Hu} \mathrm{X}$, Wang $\mathrm{T}$ and Zhang $\mathrm{X}$. Infection by $\mathrm{Cx} 43$ adenovirus increased chemotherapy sensitivity in human gastric cancer BGC-823 cells: not involving in induction of cell apoptosis. Gene. 2015; 574:217-224.

47. Yan LH, Wei WY, Cao WL, Zhang XS, Xie YB and Xiao Q. Overexpression of CDX2 in gastric cancer cells promotes the development of multidrug resistance. American journal of cancer research. 2015; 5:321-332. 
48. Garcia-Manero G, Daniel J, Smith TL, Kornblau SM, Lee MS, Kantarjian HM and Issa JP. DNA methylation of multiple promoter-associated $\mathrm{CpG}$ islands in adult acute lymphocytic leukemia. Clinical cancer research. 2002; 8:2217-2224.

49. Worm J, Kirkin AF, Dzhandzhugazyan KN and Guldberg P. Methylation-dependent silencing of the reduced folate carrier gene in inherently methotrexate-resistant human breast cancer cells. The Journal of biological chemistry. 2001; 276:39990-40000.
50. Kobow $\mathrm{K}$ and Blumcke I. The emerging role of DNA methylation in epileptogenesis. Epilepsia. 2012; 53:11-20.

51. Tian T, Peng S, Xiao H, Long Y, Fu B, Zhang X, Guo S, Wang S, Zhou X, Liu S and Zhou X. 5-Methyldeoxycytidine enhances the substrate activity of DNA polymerase. Chemical communications. 2013; 49:10085-10087.

52. Carli D, Honorat M, Cohen S, Megherbi M, Vignal B, Dumontet C, Payen L and Guitton J. Simultaneous quantification of 5-FU, 5-FUrd, 5-FdUrd, 5-FdUMP, dUMP and TMP in cultured cell models by LC-MS/MS. J Chromatogr B Analyt Technol Biomed Life Sci. 2009; 877:2937-2944. 